\title{
Differential Treatment in Environmental Law: Addressing Critiques and Conceptualizing the Next Steps
}

\author{
Philippe Cullet"
}

\begin{abstract}
:
Differential treatment in international environmental law is the broader manifestation of the principle of common but differentiated responsibilities (CBDRs). It reflects equity concerns that have underlain most environmental debates on a North-South basis for several decades. Over the past couple of decades, different forms of differentiation have been introduced in environmental law instruments to the point where it has become an essential element of any international environmental agreement. At the same time, differential treatment has been the object of sustained criticism, arguing that it should be temporary, that it fails to target beneficiaries appropriately, and undermines environmental outcomes. This article takes the opposite view and argues that differentiation remains crucial in a world where widespread inequalities remain. Beneficiaries need to be identified on the basis of environmental and social indicators and differentiation should constitute the basis on which environmental measures are adopted. Worsening environmental conditions and an evolving global context call for adding new elements to the existing framework for differentiation. This requires thinking beyond the current structure centered around nation states and conceptualizing differentiation around common heritage equity. It also requires expanding differentiation beyond the field of environmental law, to include all areas of sustainable development law. Further, differential treatment needs to be implemented in a way that benefits the most disadvantaged in every country. These measures are necessary to foster a vibrant international environmental law that addresses the equity needs of all states in years to come.
\end{abstract}

\section{Keywords: Differential treatment; Equity; Development; North- South; Distributive justice; Redistribution}

\footnotetext{
* SOAS University of London, School of Law, London (United Kingdom).

Email: pcullet@soas.ac.uk.
} 


\section{INTRODUCTION}

Differential treatment between different groups of countries constitutes one of the bases of existing international environmental law (IEL). In most cases, it is a distinction between developed and developing countries that has structured treaties. This differentiation is firmly anchored in the structure of IEL that cannot be understood without reference to the various measures taken to reflect the situation of developing and least developed countries (LDCs).

There is a direct link between differentiation and equity. In fact, differential treatment constitutes one of the most visible - and hence also controversial - instruments to foster equity in IEL. ${ }^{1}$ It builds on ideas of global distributive justice and helps to rebalance some of the most visible inequalities arising between formally equal states of very different size, power or natural resource endowments.

There have been multiple restatements of the principle of common but differentiated responsibilities (CBDRs or CBDR principle) in recent years, including at the United Nations (UN) summit for the adoption of the post-2015 development agenda. ${ }^{2}$ This confirms the central position of differentiation and the intrinsic link between a form of equity and existing IEL. This is not surprising in a context where 29 years after the release of the Brundtland Commission report, ${ }^{3}$ states have tackled neither inequality nor poverty. Differentiation is and will remain necessary for the majority of countries of the South for decades to come and for the billions of people whose human rights, including environment-related human rights, are not fully realized.

This article starts with a restatement of the conceptual bases for differential treatment. This restatement confirms the significance of the break proposed with the traditional international legal framework and explains the continuing opposition to differential treatment by some countries. Section three moves on to analyze the varied ways in which differentiation has

1 The conceptual framework for differential treatment is articulated in detail in P. Cullet, Differential Treatment in International Environmental Law (Ashgate, 2003).

2 UN General Assembly Resolution 70/1, Transforming our World: The 2030 Agenda for Sustainable Development, UN Doc. A/RES/70/1 (2015), Declaration, para. 12, available at: http://www.un.org/ga/search/view_doc.asp?symbol=A/RES/70/1\&Lang=E.

3 Report of the World Commission on Environment and Development, Our Common Future, UN Doc. A/42/427 (1987), available at: https://daccess-ods.un.org/TMP/7678504.58621979.html. 
been introduced in IEL and shows that differential treatment has become a basic element that pervades the whole field. While debates tend to focus specifically on the presence or absence of CBDRs, this section shows that the reality is much more complex and that differentiation arises in many forms and places. The fourth section addresses some critiques of differentiation. It argues that differentiation remains as necessary as two decades ago because of continuing inequalities between the North and the South. It also responds to the criticism that a simple North-South division fails to provide a way to differentiate large economies and polluters from small LDCs and argues that differentiation should primarily be based on environmental and social factors. Further, it asserts that differential treatment does not undermine environmental outcomes but is rather a necessary pre-condition for stronger environmental outcomes at the global level. The fifth section contemplates novel elements that need to be considered to strengthen differential treatment in the future and to better reflect the evolution and complexity of an increasingly global world. It argues that differentiation needs to leave behind the conceptual framework that makes us look at global environmental problems through the lens of the nation state in favour of a framework based on common heritage equity. A broader framework is also necessary so that differential treatment is applied to all connected fields in the wider realm of sustainable development. This is a necessary pre-condition to ensure that all fields of sustainable development are covered by the same principles. Further, differential treatment needs to be implemented in such a way that it benefits the most disadvantaged in every country.

\section{BASES FOR DIFFERENTIATION: EQUITY AND PRA GMAT IS M}

Differentiation is a relatively novel phenomenon in international law. Its development is directly linked to the rapid increase in the number of states following decolonization which fundamentally changed the nature of the 'international community'. ${ }^{4}$ Indeed, countries newly recognized as states often shared a common past of colonial exploitation and a relatively similar socio-economic profile, very different from other countries that had been recognized as states for much longer.

4 On the 'international community', see, e.g., D. Kritsiotis, 'Imagining the International Community' (2002) 13(4) European Journal of International Law, pp. 961-92. 
The development of differentiation can be explained from two different perspectives. Firstly, differential treatment is based on a recognition that deep inequalities must be addressed to ensure the legitimacy of the international legal order. Equity is at the root of measures that seek to foster substantive equality in a world structured around formal equality. ${ }^{5}$ Secondly, differentiation is the product of the convergence of different interests in international negotiations that offer a basis for diverging from the usual reciprocity of obligations. In IEL, differential treatment reflects equity considerations, as well as the necessity for the North to offer suitable conditions to countries of the South to entice them to join environmental regimes on issues of global importance. ${ }^{6}$

Structurally, differential treatment constitutes a recognition of the limits of a system based on a fiction of legal equality between states that imposes reciprocity of commitments by all state parties to any treaty. ${ }^{7}$ It is not the first type of measures taken to address the problems that may be caused by the strict application of the principle of reciprocity. Indeed, it has been recognized for decades that judges should have the flexibility to apply strictly reciprocal rules in ways that go beyond mechanical application of the rule to ensure a just and fair result. ${ }^{8}$ This flexibility provides a tool for the judge to ensure that the decision given in a particular case is not perceived as illegitimate. ${ }^{9}$ This form of equity is well accepted and the International Court of Justice (ICJ) has ruled that '[e]quity as a legal concept is a direct emanation of the idea of justice'. ${ }^{10}$ In certain cases, such as maritime delimitation, the ICJ has taken into account geographical factors in its reasoning but it has however refused to consider socio-economic factors such as levels of economic development since these are deemed not to be permanent features. ${ }^{11}$

5 See P. Cullet, 'Differential Treatment in International Law: Towards a New Paradigm of Inter-State Relations’ (1999) 10(3) European Journal of International Law, pp. 549-82, at 551.

6 See A. Gallagher, 'The "New" Montreal Protocol and the Future of International Law for the Protection of the Global Environment' (1992) 14(2) Houston Journal of International Law, pp. 267-364, at 311.

7 D.B. Magraw, 'Legal Treatment of Developing Countries: Differential, Contextual and Absolute Norms' (1990) 1 Colorado Journal of International Environmental Law \& Policy, pp. 69-100.

8 See A. Gourgourinis, 'Delineating the Normativity of Equity in International Law' (2009) 11(3) International Community Law Review, pp. 327-47.

9 See M. Akehurst, 'Equity and General Principles of Law' (1976) 25(4) International \& Comparative Law Quarterly, pp. 801-25.

10 Continental Shelf (Tunisia/Libyan Arab Jamahiriya), Judgment, ICJ Reports 1982, p. 18, at para. 71.

11 Maritime Delimitation in the Area between Greenland and Jan Mayen, Judgment, ICJ Reports 1993, p. 38, at para. 80 . 
The main shortcoming of judicial equity is its incapacity to take into account structural inequalities in the medium or long term, such as inequalities in levels of human or economic development. Indeed, a solution limited to individual cases does not provide a sufficient basis for the legal system to offer just outcomes if the result of the application of norms is mostly unfair. This requires rethinking the structure of the rules and moving away from the idea of strict reciprocity. ${ }^{12}$ This is what differential treatment at the level of norms can achieve. The differentiation that is at stake here is one that ensures a reduction in inequality, that prevents an increase in inequality and more generally that leads to results that are more just than without differentiation.

Differential treatment seeks to foster substantive equality where formal equality does not lead to adequate results. Different conceptions of justice can provide a justification for differential treatment in IEL. The first is corrective justice, which leads to a focus on the differential historical contributions of states to environmental degradation. The most debated case in this context is climate change since a direct correlation exists between greenhouse gas (GHG) emissions over the past couple of centuries and present levels of per capita economic development. ${ }^{13}$ This need not be restricted to climate change and could include exploitation of environmental and natural resources during the colonial period. Yet, while differential treatment has strong roots in corrective justice, the North has not agreed to an understanding of the principle of CBDRs that includes a historical dimension. ${ }^{14}$

The second conception of justice at the root of differentiation is distributive justice. This focuses on the need to address existing inequalities in human development. In a context where the legal framework equates justice with formal equality, distributive justice reminds us that it is not sufficient to provide for equality of chances but that what matters is equality of results. ${ }^{15}$ Consequently, like cases should be treated alike and dissimilarly situated people should be treated dissimilarly. ${ }^{16}$ In the Aristotelian formulation, dissimilar situations need to

12 See E. Decaux, La réciprocité en droit international (Librairie générale de droit et de jurisprudence, 1980).

13 Concerning corrective justice, see E.A. Posner \& C.R. Sunstein, 'Climate Change Justice' (2007-2008) 96(5) Georgetown Law Journal, pp. 1565-612.

14 K. Bartenstein, 'De Stockholm à Copenhague: Genèse et évolution des responsabilités communes mais différenciées dans le droit international de l'environnement' (2010) 56(1) McGill Law Journal, pp. 177 230 , at 187.

15 See F. Fukuyama, The Origins of Political Order: From Prehuman Times to the French Revolution (Profile Books, 2012).

16 H.L.A. Hart, The Concept of Law, $2^{\text {nd }}$ Ed. (Clarendon, 1994), p. 159. 
be addressed in ways that take into account existing differences. ${ }^{17}$ This perspective has been accepted for decades in international law, as confirmed by ICJ Justice Tanaka's admonition that ' $[\mathrm{t}] \mathrm{o}$ treat unequal matters differently according to their inequality is not only permitted but required'. ${ }^{18}$ Internationally, in view of prevailing massive inequalities, it is imperative to take measures to address such inequalities. Yet, measures taken to address them, such as economic redistribution of resources, have remained contentious in the North, which has shied away from recognizing any entitlement linked to justice claims for such redistribution. ${ }^{19}$ Indeed, even Rawls, whose theory of justice gave a more humane touch to liberal philosophy, ${ }^{20}$ finds that once the duty of assistance is satisfied at the international level and all people have working liberal or decent governments, 'there is again no reason to narrow the gap between the average wealth of different peoples' ${ }^{21}$ Stone argues in a similar manner when he opines in the context of an environmental discussion that:

even if we suppose that the present worldwide distribution of wealth is so unsupportable that some Rich to Poor redistributions are in order, it is an additional leap to defend redistributions within the matrix of a particular framework, such as a multilateral environmental agreement. Why should redistribution be sought through exempting the Poor from efficient environmental and resource standards--giving them a 'right to pollute' --rather than through a more straightforward step-up in aid and development assistance?

The points made by Rawls and Stone do not address the need for the international legal framework to remain legitimate, and to be so in the eyes of the majority of the world's countries and people. Asserting that inequalities need no further attention once a framework of formal legal equality has been established, is an inappropriate way to address the world's reality. Success should be measured by the way in which desired environmental and social

17 Aristotle, The Nicomachean Ethics (translated by D. Ross, revised by J.L Ackrill \& J.O. Urmson, Oxford University Press, 1991).

18 South West Africa, Second Phase, Judgment - Dissenting Opinion of Judge Tanaka, ICJ Reports 1966, p. 6 , at 306.

19 See D. French, 'Global Justice and the (Ir)relevance of Indeterminacy' (2009) 8(3) Chinese Journal of International Law, pp. 593-619, at 608.

20 J. Rawls, A Theory of Justice (Clarendon, 1972).

21 J. Rawls, The Law of Peoples (Harvard University Press, 1999), p. 114.

22 C.D. Stone, 'Common but Differentiated Responsibilities in International Law' (2004) 98 American Journal International Law, pp. 276-301, at 293-4. 
outcomes are reached. ${ }^{23}$ In this context, differential treatment gives international law a basis to reach fair outcomes in the context of the deep inequalities among states. This must be expressed, first of all, through measures of intra-generational equity, since the primary duty of the legal framework is to foster decent and improving conditions of life for the present generation. At the same time, since any environmental measure adopted has a temporal angle, the needs of future generations must also be taken into account through measures of intergenerational equity. ${ }^{24}$

\section{DIFFERENTIAL TREATMENT:AN IN DISPENSABLE STRUCTURING ELEMENT OF INTERNATIONAL ENVIRONMENTAL LA W}

Differential treatment developed rapidly in IEL. This is largely because the different agendas of the South and North at the international level needed to find common ground on a variety of international environmental issues. The South articulated the same kind of equity claims that had already been made relatively unsuccessfully in international economic law. ${ }^{25}$ The North found itself in the position of seeking measures to address global problems, such as the hole in the ozone layer or climate change, that were not (yet) crucial environmental problems for the South when negotiations started. The middle ground between the divergent and sometimes opposed positions was paved through the development of the various forms of differential treatment that exist today in IEL.

Differential treatment is the instrument that takes forward the perceived need to foster equity in the legal framework not only at the level of the application of existing norms but in the establishment of norms themselves. In IEL, various forms of differentiation have developed over time. As a result, it has become so widespread as to be an intrinsic part of IEL. We first find differential treatment in some of the basic instruments of IEL and the principles they lay down. The 1972 Stockholm Declaration already recognized the importance of intergenerational equity, linked 'under-development' to the necessity to provide financial and Governance' (2011) 22(1) Yearbook of International Environmental Law, pp. 3-36, at 3.

25 See J. Makarczyk, Principles of a New International Economic Order (Nijhoff, 1988). 
technical aid, and called on the North to ensure that environmental technologies be made available to developing countries on terms which would encourage their wide dissemination without constituting an economic burden on the South. ${ }^{26}$ Twenty years later, references to differentiation had become much more specific. The 1992 Rio Declaration linked the realization of the right to development to meeting equitably the needs of present and future generations, recognized the necessity to give special priority to LDCs and the most environmentally vulnerable countries, and put forward in its Principle 7 the necessity of a partnership to address global environmental damage based on the principle that 'States have common but differentiated responsibilities'. ${ }^{27}$

Differential treatment is thus well enshrined in the foundational instruments of IEL. There is, however, no specific reference to a necessity to differentiate at the level of legal commitments in the basic principles of IEL. Rio Principle 7 recognized differences between the North and the South, such as in terms of contributions to environmental degradation, but it did not go as far as imposing legal obligations on the North. Indeed, the United States (US) specifically indicated that it did not believe Principle 7 could be interpreted as creating any obligation or liability for the North. ${ }^{28}$ Commentators often take a similar line and argue against the existence of binding commitments of differentiation to be borne by the North. ${ }^{29}$

Principle 7 is significant because it constitutes one of the specific battlegrounds around which differentiation is debated. It is specifically integrated in some treaties, such as the 1992 United Nations Framework Convention on Climate Change (UNFCCC), ${ }^{30}$ and has been affirmed in various legal instruments over the past two decades. This includes restatements in preambles, including in the 2001 Stockholm Convention on Persistent Organic Pollutants

26 Declaration of the United Nations Conference on the Human Environment, Stockholm, 16 June 1972, UN Doc. A/CONF.48/14/Rev.1, available at: http://www.unep.org/Documents/Default.asp?documentID=97\&ArticleID=1503, Principles 2, 9, 20.

Rio Declaration on Environment and Development, 14 June 1992, Doc. A/CONF.151/26/Rev. 1 (Vol. I), Annex II (1992), available at: http://www.un.org/documents/ga/conf151/aconf15126-1annex1.htm, Principles 2, 6, 7 .

28 Report of the United Nations Conference on Environment and Development (Rio de Janeiro, 3-14 June 1992), UN Doc. A/CONF.151/26 (Vol. IV) (1992), available at: http://www.un.org/documents/ga/conf151/aconf15126-4.htm.

29 See J.-M. Arbour, 'La normativité du principe des responsabilités communes mais différenciées' (2014) 55(1) Cahiers de Droit, pp. 33-81, at 37, Th. Deleuil, 'The Common but Differentiated Responsibilities Principle: Changes in Continuity after the Durban Conference of the Parties' (2012) 21(3) Review of European Community \& International Environmental Law, pp. 271-281 and Stone, n. 22 above at 299.

New York, NY (US), 9 May 1992, in force 21 Mar. 1994, available at: http://unfccc.int, Art. 3.. 


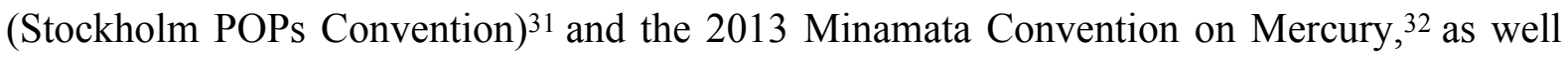
as in programmatic instruments, such as the UN's 2030 Agenda for Sustainable Development. ${ }^{33}$ In some instances, the CBDR principle has been used to guide judicial reasoning, as was the case in the Shrimp Turtle dispute in the World Trade Organization (WTO). ${ }^{34}$ The visibility of CBDRs has sometimes led to the idea that differentiation could more or less be equated with Principle 7. Yet, while CBDRs can be understood in multiple ways, there exists a variety of measures that seek to foster substantive equality without necessarily being linked to CBDRs. Differential treatment thus needs to be read as including more than what is usually discussed under the guise of CBDRs.

A variety of differential measures have been introduced in IEL. At the level of treaty norms, the most usual form of differentiation is contextualization. A reciprocal obligation is qualified by a clause, such as 'in accordance with its particular conditions and capabilities', which recognizes that member states are not all capable of taking exactly the same measures, for instance, to conserve and sustainably use biodiversity. ${ }^{35}$ Contextualization has become frequent but is disliked by some commentators who see in such clauses the germs of a weakening of the binding character of legal norms. ${ }^{36}$

Differentiation can also be enshrined in the obligations themselves, such as in the case where different states take on different commitments. The example that is most often cited of this kind of differentiation is the 1997 Kyoto Protocol to the UNFCCC, ${ }^{37}$ which only imposes GHG emissions reduction commitments on the North. The prominence of climate change generally, and in the context of debates on differentiation specifically, masks the fact that comparable measures have been adopted in other treaty regimes. Thus, the 1994 Convention to Combat Desertification in Those Countries Experiencing Serious Drought and/or

31 Stockholm (Sweden), 23 May 2001, in force 17 May 2004, available at: http://chm.pops.int.

32 Kumamoto (Japan), 10 Oct. 2013, not yet in force, available at: http://www.mercuryconvention.org.

33 UN General Assembly Resolution 70/1, n. 2 above, Declaration, para. 12.

34 United States - Import Prohibition of Certain Shrimp and Shrimp Products - Recourse to Article 21.5 by Malaysia - Report of the Panel, WTO Doc. WT/DS58/RW (2001), available at:

https://www.wto.org/english/tratop_e/dispu_e/58rw_e.pdf, para. 7.2.

35 Convention on Biological Diversity, Rio de Janeiro (Brazil), 5 June 1992, in force 29 Dec. 1993, available at: http://www.cbd.int, Art. 6.

36 cf G. Handl, 'Environmental Security and Global Change: The Challenge to International Law' (1990) 1 Yearbook of International Environmental Law, pp. 3-33, at 9 asserting that 'asymmetrical normative standards that bear on the essence of the regulatory regime, unlike incentives, are generally undesirable'.

37 Kyoto, 11 Dec. 1997, in force 16 Feb. 2005, available at: http://unfccc.int/kyoto_protocol/items/2830.php, Art. 3. 
Desertification, Particularly in Africa (UNCCD) ${ }^{38}$ includes among its principles a call to 'take into full consideration the special needs and circumstances of affected developing country Parties, particularly the least developed among them'. ${ }^{39}$ At the level of commitments, differentiation is implemented in such a way that some commitments are only borne by the North. ${ }^{40}$ The UNCCD goes further and gives the African continent a special priority. ${ }^{41}$ This has lost none of its salience in a context where the continent still counts 34 of the 48 LDCs and still deserves particular attention in terms of differentiation. The reason why differentiation in the UNCCD has attracted much less attention than in the Kyoto Protocol is partly because it is a framework convention that contains relatively general commitments. It also proved more difficult for the South to extract strong differential language in the UNCCD because the North sees desertification as more regional in scope than the Rio Conventions (UNFCCC and the Convention on Biological Diversity (CBD) ${ }^{42}$ ) and as a secondary priority. ${ }^{43}$

A series of other differentiation techniques have been gradually introduced in IEL. Several treaties offer to a group of countries the possibility to delay compliance with obligations that are strictly similar for all states. ${ }^{44}$ One of the first major treaties to do this was the Montreal Protocol on Substances that Deplete the Ozone Layer (Montreal Protocol), ${ }^{45}$ which offered developing countries with a sufficiently low level of consumption of the controlled substances a 10 -year grace period to apply the measures required by the treaty. ${ }^{46}$

Differentiation has also been introduced in other contexts, such as non-compliance procedures. ${ }^{47}$ For example, the Kyoto Protocol tasks the facilitative branch of its Compliance Committee with promoting compliance while taking into account the principle of CBDRs and

42 Rio de Janeiro (Brazil), 5 June 1992, in force 29 Dec. 1993, available at: http://www.cbd.int.

43 See T. Honkonen, The Common but Differentiated Responsibility Principle in Multilateral Environmental Agreements: Regulatory and Policy Aspects (Kluwer Law International, 2009), p. 271.

44 See Stockholm POPs Convention, n. 31 above, Art. 4(7).

45 Montreal, QC (Canada), 16 Sept. 1987, in force 1 Jan. 1989, available at: http://ozone.unep.org/new_site/en/montreal_protocol.php.

46 Ibid., Art. 5.

47 See H. Hellio, 'Le principe des responsabilités communes mais différenciées et le contrôle du non-respect: une rencontre fantasmée' (2014) 55(1) Cahiers de Droit, pp. 193-220. 
respective capabilities. ${ }^{48}$ In the yet to be adopted non-compliance procedure under the Stockholm POPs Convention, consequences may be different for the South and the North. ${ }^{49}$

In practice, one of the most visible forms of differentiation is implementation aid. ${ }^{50}$ Most treaties adopted since the early 1990s include provisions concerning implementation aid and technology transfer. ${ }^{51}$ This is linked to the progressive recognition that treaty accession by an increasing number of countries does not necessarily translate into effective implementation. It also constitutes an example of resource redistribution. ${ }^{52}$ Many states do not have the necessary financial, technological or administrative capacity to effectively implement the commitments they take at the international level. The recognition that an aid component should be added to environmental treaties is a response to this reality. The central role of access to funds and technology to implement most environmental treaties fosters the adoption of innovative provisions that recognize, for instance, that countries of the South cannot effectively implement their commitments unless countries of the North effectively fulfil their pledges concerning the transfer of financial resources and technology. 53 While implementation aid has been provided on a relatively sustained basis in various treaty regimes, the same cannot be said with regard to technology transfer, which was one of the unfulfilled promises of the New International Economic Order and remains an area of

48 Procedures and Mechanisms Relating to Compliance under the Kyoto Protocol, in Report of the Conference of the Parties serving as the meeting of the Parties to the Kyoto Protocol on its first session, held at Montreal from 28 November to 10 December 2005, UN Doc. FCCC/KP/CMP/2005/8/Add.3, available at: http://unfecc.int/resource/docs/2005/cmp1/eng/08a03.pdf, s 4(4).

49 The latest draft can be found in Decision SC-7/26, Procedures and Mechanisms on Compliance with the Stockholm Convention, in Report of the Conference of the Parties to the Stockholm Convention on Persistent Organic Pollutants on the work of its seventh meeting, UN Doc. UNEP/POPS/COP.7/36 (2015), available at: http://chm.pops.int/Portals/0/download.aspx?d=UNEP-POPS-COP.7-SC-7-26.English.pdf. See also V. Heyvaert, 'Levelling Down, Levelling Up, and Governing Across: Three Responses to Hybridization in International Law' (2009) 20(3) European Journal of International Law, pp. 647-74, at 658-9.

50 See S. Lavallée, 'Responsabilités communes mais différenciées et protection internationale de l'environnement: une assistance financière en quête de solidarité?' (2014) 55(1) Cahiers de Droit, pp. 139192.

51 See Convention on Biological Diversity, n. 35 above, Art. 20 and Minamata Convention on Mercury Kumamoto (Japan), 10 Oct. 2013, not yet in force, available at: http://www.mercuryconvention.org, Art. 14.

52 See T. Honkonen, 'The Development of the Principle of Common but Differentiated Responsibilities and its Place in International Environmental Regimes', in T. Kuokkanen et al. (eds.), International Environmental Law-making and Diplomacy: Insights and Overviews (Routledge, 2016), pp. 160-183, at 161.

53 See Convention on Biological Diversity, n. 35 above, Art. 20(4) and Stockholm POPs Convention n. 31 above, Art. 13(4). 
concern, as confirmed by recent debates in the Council for Trade-Related Aspects of Intellectual Property Rights (TRIPS) on technology transfer related to climate change. ${ }^{54}$

On the whole, differential treatment has played a central role in structuring IEL for several decades. It may take new forms over time but must remain a central feature of international environmental regulation. ${ }^{55}$ It is demanded by the broader principle of solidarity among states that requires states to take measures to address inequalities, including through differentiation..$^{56}$ This is what states did at the UN summit for the adoption of the post-2015 development agenda that calls for a global partnership for sustainable development 'based on a spirit of strengthened global solidarity'. ${ }^{57}$ It is within this context that differentiation constitutes an important tools to address the shortcomings of a system based on formal equality and to bring about substantive equality.

The importance and relevance of differential treatment needs to be restated in today's context, which emphasizes the challenges to differentiation in the climate change regime and its weakening in the Paris Agreement by the UNFCCC's $21^{\text {st }}$ conference of the parties (COP), in December 2015. ${ }^{58}$ Challenges notwithstanding, the broader lesson of the Paris Agreement is the confirmation that differentiation cannot be done away with, even if the Agreement introduces a distinct version of the principle. ${ }^{59}$ Moreover, the climate change regime remains only one of many important environmental regimes and the sectoral nature of IEL ensures

54 See Council for Trade-Related Aspects of Intellectual Property Rights, Contribution of Intellectual Property to Facilitating the Transfer of Environmentally Rational Technology - Communication from Ecuador, Doc. IP/C/W/585 (2013), available at https://docs.wto.org/dol2fe/Pages/FE_Search/FE_S_S009DP.aspx ?language $=\mathrm{E} \&$ CatalogueIdList $=115118 \&$ CurrentCatalogueIdIndex $=0 \&$ FullTextHash $=371857150$

55 cf K. Bartenstein, 'L'opérationnalisation du principe des responsabilités communes mais différenciées repensée: plaidoyer pour une démarche ancrée dans l'équité' (2014) 55(1) Cahiers de Droit, pp. 113-137, at 127 arguing that the end of differentiation would mean the end of international environmental law as we know it today.

56 cf R.St.J. McDonald, 'The Principle of Solidarity in Public International Law', in Christian Dominicé et al. (eds.), Etudes de droit international en l'honneur de Pierre Lalive (Helbing, 1993), pp. 275-308.

57 UN General Assembly Resolution 70/1, n. 2 above.

58 Paris Agreement, Paris (France), 13 Dec. 2015, not yet in force (in UNFCCC, Report of the Conference of the Parties on its Twenty-First Session, Addendum, UN Doc. FCCC/CP/2015/10/Add.1, 29 Jan. 2016, available at http://unfecc.int/resource/docs/2015/cop21/eng/10a01.pdf). See also S. Maljean-Dubois, 'The Paris Agreement: A New Step in the Gradual Evolution of Differential Treatment in the Climate Regime?' (2016) 25(2) Review of European, Comparative \& International Environmental Law, pp. 151-160.

59 L. Rajamani, 'Ambition and Differentiation in the 2015 Paris Agreement: Interpretative Possibilities and Underlying Politics’ (2016) 65(2) International \& Comparative Law Quarterly, pp. 493-514, at 509. 
that any single treaty does not signal a trend in itself. ${ }^{60}$ The central role of differentiation has in fact been clearly reiterated in recent years with every important environmental legal instrument, including new treaties such as the Minamata Convention and major UN summits, such as the 2012 Rio +20 summit ${ }^{61}$ or the 2015 Sustainable Development Goals' summit, ${ }^{62}$ which specifically restates the central importance of the CBDR principle. ${ }^{63}$

\section{THE NEED FOR DIFFERENTIAL TREATMENT TO ADDRESS INEQUALITIES AND FOSTER ENVIRONMENTALQUALITY}

Differential treatment has been subjected to various forms of criticism. These range from opposition to the very idea of differentiation in international law to criticism of the specific manner in which differential treatment has developed in IEL. This section addresses some recurrent critiques. Firstly, it engages with the recurrent criticism that differentiation may be appropriate but should be available only up to the point at which inequalities are sufficiently reduced. This may be theoretically sound, but in reality with structurally undiminished inequality and rampant poverty, more rather than less differentiation is necessary. Secondly, differential treatment is increasingly criticized because the current framework based on a simple North-South division fails to provide a way to distinguish large economies and polluters from small LDCs, often with particular reference to China as the biggest emitter of GHGs in the climate change context. In response, this article suggests that beneficiaries should be identified primarily on the basis of environmental and social indicators that are linked more directly with the subject matter of the concerned treaties. Thirdly, this section addresses the criticism that differential treatment dilutes the environmental content of international treaties. It argues on the contrary that differential treatment is so inseparable from the environmental outcomes that the former is in fact a necessary condition for positive environmental outcomes.

60 cf L. Rajamani, 'The Changing Fortunes of Differential Treatment in the Evolution of International Environmental Law' (2012) 88(3) International Affairs, pp. 605-623 at 606.

61 See UN General Assembly Resolution 66/288, The Future we Want, UN Doc. A/RES/66/288 (2012), available at: http://www.un.org/ga/search/view_doc.asp?symbol=A/RES/66/288\&Lang=E.

62 See UN General Assembly Resolution 70/1, n. 2 above.

63 cf Y. Le Bouthillier, 'Des constats et des questions sur le principe des responsabilités communes mais différenciées' (2014) 55(1) Cahiers de Droit, pp. 315-324, at 318 opining that even if CBDR gets to be diluted in the climate change context, it has already emerged in different ways in other treaty regimes. 


\subsection{The Need for Further Differentiation in an Unequal World}

Differential treatment is sometimes perceived as an acceptable temporary compromise to redress certain inequalities. At the same time, the argument runs that it should be limited in time and lead to a return to a legal order based on legal equality and reciprocal obligations. ${ }^{64}$ Such views have been given a new lease on life since the beginning of the century, in a context where a few large countries in the South have been the engine of world growth. This has led to calls to restrict or abolish differential treatment based on the argument that countries such as China are now resilient enough not to require any favours and must bear the burden of their fast increasing contribution to environmental degradation. ${ }^{65}$ The changes identified are real and the world has indeed changed significantly since the early 1990s. At the same time, the perception of change is largely driven by the focus on the economic growth of BRICS countries (Brazil, Russia, India, China, and South Africa) at a time of sluggish growth in the North. ${ }^{66}$

This tends to make us forget that there has been no significant structural change over the past few decades. Indeed, the situation of the majority of countries of the South, in particular the LDCs, is comparatively no better than it was at the beginning of the 1990s. A longer term comparison confirms this point. If the share of global gross domestic product (GDP) of the South were $30 \%$ in 1974 , it is $32 \%$ today according World Bank estimates. ${ }^{67}$ Thankfully, there has been a faster progression of the Human Development Index (HDI) in countries at the bottom of the scale. Yet at the same time, while countries with low human development saw their HDI increase from 0.315 in 1980 to 0.505 in 2014, countries with very high human development also saw their HDI increase significantly from 0.773 to 0.896 during the same period. ${ }^{68}$

Thus, there is neither a reason to celebrate the progression in the South over the past few decades, nor a reason to be preoccupied by a situation where inequalities between the North

See Y. Matsui, 'Some Aspects of the Principle of "Common but Differentiated Responsibilities"' (2002) 2(2) International Environmental Agreements: Politics, Law and Economics, pp. 151-171.

cf J.C. Nagle, 'How Much Should China Pollute?' (2011) 12 Vermont Journal of Environmental Law, pp. 591-632.

See Anonymous, 'The BRICs - The Trillion-dollar Club', The Economist 15 April 2010, available at http://www.economist.com/node/15912964.

7 World Bank, World Development Indicators (Table 4.2 - Structure of output) (2015).

UNDP, Human Development Report 2015 (UNDP, 2015). 
and the South would be so reduced as to make differential treatment redundant. The idea that differentiation must be dynamically interpreted is a valid proposition, ${ }^{69}$ but it presupposes a context in which structural inequalities are showing sign of significantly decreasing.

Since inequalities in levels of human development have not diminished significantly, the moral imperative for differential treatment remains as strong as it was a couple of decades ago. The need to 'combat inequalities' is in fact one of the specific commitments taken by the UN summit for the adoption of the post-2015 development agenda. ${ }^{70}$ The need for further differentiation has also been confirmed recently by the WTO, an institution set up in 1995 on the premise of the need to dispense with differentiation and treat all states on a basis of formal equality. ${ }^{71}$ In the context of the Trade-Related Aspects of Intellectual Property Rights (TRIPS) Agreement, ${ }^{72}$ staggered implementation had been originally agreed. Developed countries had to implement their commitments by 1 January 1996, developing countries by 1 January 2000 and the LDCs were given an extension until 1 January $2006 .{ }^{73}$ The deadline for LDCs was subsequently extended to 2013 and subsequently to $2021 .{ }^{74}$ This now amounts to a 25-year extension on the original 1996 implementation deadline for developed countries and indirectly confirm the increasingly shared understanding that LDCs have very little, if anything to gain from the TRIPS Agreement. ${ }^{75}$

69 cf S. Maljean-Dubois \& P. Moraga Sariego, 'Le principe des responsabilités communes mais différenciées dans le régime international du climat' (2014) 55(1) Cahiers de Droit, pp. 83-112, at 104.

70 UN General Assembly Resolution 70/1, note 2 above, Declaration, para. 3.

71 See C. Michalopoulos, Role of Special and Differential Treatment for Developing Countries in GATT and the World Trade Organization (World Bank, 2000).

72 Agreement on Trade-Related Aspects of Intellectual Property Rights, Marrakesh (Morocco), 15 Apr. 1994, in force 1 Jan. 1995, available at https://www.wto.org/english/tratop_e/trips_e/t_agm0_e.htm.

73 Ibid., Art. 65-66.

74 Council for Trade-Related Aspects of Intellectual Property Rights, Extension of the Transition Period Under Article 66.1 for Least Developed Country Members, Decision of the Council for TRIPS of 29 November 2005, WTO Doc. IP/C/40 (2005), available at: https://docs.wto.org/dol2fe/Pages/FE_Search/FE_S_S009-

DP.aspx language $=$ E\&CatalogueIdList $=75909 \&$ CurrentCatalogueIdIndex $=0 \&$ FullTextHash $=371857150$ and Council for Trade-Related Aspects of Intellectual Property Rights, Extension of the Transition Period Under Article 66.1 for Least Developed Country Members, Decision of the Council for TRIPS of 11 June 2013, WTO Doc. IP/C/64 (2013), available at: https://docs.wto.org/dol2fe/Pages/FE_Search/FE_S_S009DP.aspx ?language $=\mathrm{E} \&$ CatalogueIdList $=117294 \&$ CurrentCatalogueIdInde $=0 \&$ FullTextHash $=\overline{3} 71857150$

75 cf Nuno Pires De Carvalho, The TRIPS Regime of Patent Rights (Kluwer Law International, 2002) arguing that higher standards of protection for patents are a trade-off that ensures that developing countries are entitled to lower tariffs on their exports to developed country markets. 
Overall, the limited improvements over the past couple of decades in terms of inequality in human development between the North and South in general, and small developing and least developing countries in particular, confirms that differentiation is needed more than ever. It is often countered in response that, if this is true, it cannot hold for all countries of the South in the same way. Others responses argue that inequalities may be present but that differential treatment is not the answer because it undermines environmental outcomes in the name of benefiting the South. The next two sub-sections address these criticisms.

\subsection{Towards Selective Differentiation Based on Environmental and Social Criteria}

One criticism levelled at differential treatment in recent years refers to its monolithic view of beneficiaries, whereas the situation of some large countries of the South has changed significantly over the past couple of decades. This is in essence the debate that surrounded the Kyoto Protocol and the growing demand for some countries of the South to take on some kind of commitments under the climate change regime in view of their contribution to environmental degradation and their increasing resilience. The critique can be used in support of a proposal to abolish differentiation or to introduce new grounds on which to base differential measures. This article argues instead that differentiation is needed and responds to the critique by looking at alternative criteria for differentiation which can provide a better model for the future.

The present framework for differentiation is built around an existing distinction between 'developed' and 'developing' countries that itself coincides in large part with formerly colonizing and colonized countries. In the context of international economic law in which early debates on preferential treatment took place, this division on the basis of economic criteria was an appropriate starting point. ${ }^{76}$ In the environmental sphere, there were also good reasons to start with this same division: 'developed' and 'developing' were known categories and in some cases a good correlation existed between levels of economic development and contribution to environmental damage. This was, for instance, the case for the generation of hazardous wastes and contribution to GHG emissions.

76 See N. Schrijver, Sovereignty over Natural Resources - Balancing Rights and Duties (Cambridge University Press, 1997). 
At the same time, the simplistic division of the world in North and South was reductionist and became the target of criticism. There has been relatively limited movement towards refining the categorization of states in environmental agreements even though the need has been acknowledged. ${ }^{77}$ The Paris Agreement is the first to decisively break with the NorthSouth dichotomy by providing for 'nationally determined contributions' (NDCs) that each country intends to achieve. ${ }^{78}$ Yet this instrument does not constitute a model for the future since it only constitutes a victory in the face of the no-agreement option that could have put an end to any hope for an effective form of international cooperation on climate change. ${ }^{79}$

From a differential treatment perspective, the Paris Agreement seems to break new ground by proposing a form of individual differentiation. Yet, the way in which this was introduced is self-defeating since it is led by individual self-interest of states rather than by international ambition. The problem is not with individual differentiation whose need has been recognized for years, ${ }^{80}$ but with self-differentiation. Indeed, there is a basic difference between differentiation based on individual preferences and self-interest of countries and individual differentiation arising as a result of an internationally agreed upon framework. While IEL is yet to move towards negotiated individual differentiation, this is not unknown per se at the international level, as reflected in the case of the UN budget to which member states contribute on the basis of an individual assessment by the institution of their capacity to pay, rather than on the basis of a self-assessment. ${ }^{81}$

The failure of recent agreements to move beyond a North-South dichotomy, or as in the case of the Paris Agreement to provide a future model for differential treatment, necessitates new thinking about criteria that could become the basis for differentiation and that would avoid the pitfalls of the current approach. In IEL, categorization according to a measure of economic development needs to make way for environmental and social criteria that should Differentiated Responsibilities’ (2013) 13(5) Climate Policy, pp. 589-607, at 603.

79 cf D. Bodansky, 'The Paris Climate Change Agreement: A New Hope?' (forthcoming 2016) 110 American Journal International Law and W. Obergassel et al., Phoenix from the Ashes - An Analysis of the Paris Agreement to the United Nations Framework Convention on Climate Change (Wupertal Institute for Climate, Environment and Energy, 2016).

80 eg Cullet, $\mathrm{n} 1$ above at 53.

81 See UN General Assembly Resolution 70/245, Scale of Assessments for the Apportionment of the Expenses of United Nations, 23 December 2015, UN Doc. A/RES/70/245, available at: http://www.un.org/en/ga/search/view_doc.asp?symbol=A/RES/70/245. 
be linked much more directly to the subject matter of the treaties being negotiated. While it has been suggested that differentiation should be based on objective mathematical criteria, ${ }^{82}$ poverty, impoverishment or environmental degradation cannot necessarily be determined through numbers.

In the future, differential treatment should be based on a social and environmental assessment that identifies countries' vulnerability and resilience to environmental problems. This will have several advantages. Firstly, it will help to bring back the environmental agenda to the centre of environmental treaties. In the context of climate change, for instance, this is a real concern since debates tend to centre around economic development strategies. The focus has been mostly on the extent to which countries should be allowed to pollute the atmosphere. This is not completely unexpected in a context where the central issue of common but differentiated responsibilities and respective capabilities (CBDR-RC) has been framed around a division of the world according to economic development criteria. Yet, the environmental issue of climate change requires the world to think about the climate from an environmental perspective and on the basis of environmental principles. Thus, a climate change legal instrument ideally should propose, on the basis of the precautionary principle, differentiated obligations to take precautionary measures to mitigate and adapt to climate change. This would have the advantage of building obligations around the necessity for each country to reduce its impact on the global environment rather than the present system based around rights to pollute that indirectly legitimize the higher emissions of more polluting countries.

Secondly, social and environmental indicators will provide a much better basis for differentiating between countries. For instance, China and Malawi have little in common in terms of their respective responsibilities for global environmental harm, their resilience to harm and their capacity to address the consequences of environmental harm. Their different status is highlighted by the fact that China is now one of the main donor countries to least developed African countries. ${ }^{83}$ While China and Malawi are leagues apart in terms of levels of human development, Fiji happens to have the same rank as China in terms of its HDI

83 See A. Strange et al., China's Development Finance to Africa: A Media-Based Approach to Data Collection (Center for Global Development, 2013). 
ranking. ${ }^{84}$ Yet, as a small-island state, Fiji's contribution and needs in the face of climate change and sea-level rise cannot be compared to China's situation.

On the whole, several factors bear out the need for change in the way beneficiaries of differentiation are identified. Change is first needed to ensure that the lack of distinction within the broad North-South categories does not become a wedge to abolish differentiation altogether. It is also needed to bring differentiation in IEL closer to its subject matter. The categorization along economic development lines was a useful proxy and a politically convenient tool to help the development of differential treatment measures. A few decades later, it is time to move towards using environmental and social indicators that mirror the substance of the treaties negotiated in the broader context of sustainable development which informs IEL today.

\subsection{Differentiation as a Necessary Basis for Successful Environmental Measures}

Some view differential treatment as a double-edged instrument that may generate positive outcomes for the South at the expense of the environment. Two different critiques can be highlighted. It has been suggested that differential treatment does not necessarily provide the basis for agreements favourable to sustainable development ${ }^{85}$ Here, the very presence of differentiation is seen as the root cause of the dilution of environmental measures. From a different perspective, it has been suggested that within the context of a given treaty, the extent of differential treatment should preferably 'be limited in the service of the object and purpose of the treaty'. ${ }^{86}$

Differentiation is thus portrayed as a factor that limits the potential ideal environmental outcome or that needs to be constrained to ensure it does not affect the environmental goals of a treaty. However, differentiation must be appreciated in the much more positive light in which it first arose. Differentiation, or equity, is an intrinsic part of sustainable development, as for instance reflected in its inclusion in the Rio Declaration. There cannot be sustainable

86 L. Rajamani, Differential Treatment in International Environmental Law (Oxford University Press, 2006), p. 159. 
development at the international level without differentiation, which has been confirmed in international environmental treaties over the past few decades.

An (environmentally) successful treaty is thus one in which environmental obligations have a differential basis. Differentiation cannot have negative impacts on the environmental content of a treaty to the extent that it is at the root of the consensus position that is arrived at in the final negotiated text of an instrument. Indeed, none of the main international treaties adopted since the 1980s would have been widely ratified if it were not for their differential component. The first example is probably the Montreal Protocol, ${ }^{87}$ a treaty the South would not have joined if it did not take into account the necessity to differentiate between the North and the South. ${ }^{88}$ Differential treatment needs to be seen against the baseline of the absence of agreement rather than against the ideal treaty that would do all that could be expected in environmental terms. The latter is, in any case, an impossibility when the framework of reference is sustainable development rather than only environmental conservation. IEL is intrinsically about compromizes between different worthy goals, equity and environmental conservation being two of them.

Differentiation has also been criticized for introducing double standards of environmental protection. The absence of reciprocity is considered to potentially weaken the juridical nature of the norms adopted. ${ }^{89}$ Economists see in these double standards an incentive for multinational companies to target countries with the weakest environmental regulation, with negative consequences for the South. Matsui concludes thus that '[a] consequence of this might be an environmental disaster such as the Bhopal incident that occurred in India in 1984'.90 This is an important remark for this discussion. On the one hand, it has been established that Union Carbide's security measures were not the same for its similar plants in Institute, West Virginia and in Bhopal. ${ }^{91}$ This indeed matches the profile of a multinational company searching for investment opportunities that are less burdensome in human and environmental terms. On the other hand, the Bhopal disaster preceded the introduction of

\footnotetext{
87 Montreal Protocol, n. 45 above.

88 Gallagher, n. 6 above at 356.

89 See A. Boyle, 'Comments on the Paper by Diana Ponce-Nava', in W. Lang (ed.), Sustainable Development and International Law (Graham \& Trotman, 1995), p. 137, at 139-40.

90 Matsui, n. 64 above at 158.

91 See Amnesty International, India: Clouds of Injustice: Bhopal Disaster 20 Years on (Amnesty International, 2004), p. 42.
} 
differential treatment and non-reciprocity in IEL and was therefore in no way caused by differentiation. Rather, the Bhopal disaster contributed to the strengthening of environmental law in India, ${ }^{92}$ and constituted a reference point in international negotiations for years, confirming that countries of the South face special problems that necessitate differential measures.

Conversely, differential treatment should not be seen as putting an additional burden on countries of the South to take environmental protection measures that they would not take otherwise. Generally, the South does not lag behind the North in terms of adopting environmental laws. More specifically, fast decreasing environmental quality in countries of the South acts as a strong incentive to take measures that may 'cost' in economic terms but contribute to sustainability, including environmental quality and human health. This is the case, for instance, with regard to catastrophic air pollution in various cities in the South, which acts as a strong incentive for regulatory measures, regardless of climate change international initiatives concerning. ${ }^{93}$ There is thus no opposition between differentiation and environmental protection. Again, this is not surprising since the framework of reference is the notion of sustainable development, rather than only environmental conservation.

\section{RETHINKING ENVIRONMENTAL DIFAERENTIATION INAGLOBALIZEDWORLD}

Differential treatment has been successfully implemented over the past couple of decades to the extent that North-South equity measures now constitute an essential component of IEL. This is not to say that the global environment fares much better than it did a few decades ago. In fact, the world faces an increasingly long list of worsening environmental problems.

This calls for new thinking on differential treatment, something that can be done from two different perspectives. Some see the weakening of differentiation in the Paris Agreement as a positive sign that the climate change regime has moved ahead of a 'bipolar, rigid and static

92 See M. Niyati, 'Judicial Activism for Environment Protection in India' (2015) 4(4) International Research Journal of Social Sciences, pp. 7-14.

93 In the case of Delhi's air pollution and early interventions of the Supreme Court of India, see A. Rosencranz \& M. Jackson, 'The Delhi Pollution Case: The Supreme Court of India and the Limits of Judicial Power' (2003) 28 Columbia Journal of Environmental Law, pp. 223-254. 
type of differentiation' in the Kyoto Protocol. ${ }^{94}$ However, this article argues that differentiation needs to be rethought to reflect a world where inequalities have not substantially reduced but environmental harm has significantly increased.

This section first argues that the nature of the problems at stake should be at the centre of regulatory measures rather than national self-interest. In a context where many environmental problems are global in scope, the principle of common heritage provides an appropriate alternative to rethink differentiation. Moreover, the scope of differential treatment should be broadened beyond the relatively narrow field of the environment to cover all issues related to sustainable development. Finally, it is argued that differentiation must consider the place and role of non-state actors to ensure that international measures do not disadvantage the poorest in a given country.

\subsection{Rethinking the Basis for Differentiation: Common Heritage Equity}

Differential treatment is based on a territorial understanding of the world that has no relationship with the nature of the problems addressed. While thinking beyond sovereign entities may sound utopian in a world still largely defined by nation states, there are good reasons why the environmental sphere should be one of the first where such new thinking is introduced. Environmental problems typically do not recognize state boundaries. Further, the global environmental problems that have been at the centre of the development of differential treatment are quintessentially unsuited to a territorial division perspective.

Conceptually, there is a need to move beyond the idea of ownership of environmental resources by individual states to an understanding that certain resources are in the custody of the whole of humankind. ${ }^{95}$ Once these resources are defined as 'common heritage', ${ }^{96}$ they become something that cannot be owned by anyone, that must be managed jointly and the benefits of which are also enjoyed jointly. This provides an avenue to look at their regulation in a new light that transcends national self-interest.

95 Th.M. Franck, 'Fairness in the International Legal and Institutional System' (1993) 240 Collected Courses of the Hague Academy of International Law, pp. 9-498, at 92.

96 See S. Stec, 'Humanitarian Limits to Sovereignty: Common Concern and Common Heritage Approaches to Natural Resources and Environment' (2010) 12(3) International Community Law Review, pp. 361-389. 
Centuries of sovereign assertion over natural resources have ensured that the very notion of common ownership of the earth's resources remains controversial because it challenges the basic principles of the established legal framework. ${ }^{97}$ Yet, international law witnessed the introduction of the concept of common heritage of humankind several decades ago. ${ }^{98}$ Debates around its introduction centred around an equity rationale, which mirrors the discussion above concerning existing differential treatment measures. ${ }^{99}$ The starting point was the status of resources which had not yet been claimed in ownership, such as deep seabed minerals. This provided the basis for discussing ways in which these resources should be managed by all states together, regardless of their actual technological or financial capacity to exploit them.

The existing regime for the conservation and use of resources of the Area ${ }^{100}$ in the UN Convention on the Law of the Sea (UNCLOS) constitutes a model that can be built on. It involves a form of global redistribution of resources in the form of common heritage equity that is similar in intent to differential treatment. Under common heritage equity, exploitation of the concerned resources is not governed by the 'first-come, first-served' rule that has been the basis of appropriation of territory and resources for centuries, but rather by a recognition of broader values that endorse a form of joint management and sharing of the benefits. ${ }^{101}$ While the UNCLOS regime is oriented more towards equitable resource allocation than conservation, there is no a priori reason why the latter cannot be as strong as the former. This can be seen in the context of Antarctica where the freeze on sovereign claims has not stopped

97 Stockholm Declaration, n. 26 above, Principle 21 and Rio Declaration, n. 27 above, Principle 2.

98 See S.J. Shackelford, 'The Tragedy of the Common Heritage of Mankind' (2009) 28 Stanford Environmental Law Journal, pp. 109-169, at 116.

99 See M.C.W. Pinto, 'The Common Heritage of Mankind: Then and Now' (2013) 361 Collected Courses of the Hague Academy of International Law, pp. 9-118 noting at 110 that ' $[\mathrm{t}] \mathrm{o}$ the majority of participants at the Third United Nations Conference on the Law of the Sea "common heritage of mankind" came to imply distributive justice, cooperation and preferential treatment for the poor'.

100 The UN Convention on the Law of the Sea (UNCLOS), Montego Bay (Jamaica), 10 Dec. 1982 , in force 16 Nov. 1994, available at:

http://www.un.org/depts/los/convention_agreements/convention_overview_convention.htm, defines the Area at Art. 1(1)1 as 'the sea bed and ocean floor and subsoil thereof, beyond the limits of national jurisdiction'. The regime for the regulation of activities in the Area is detailed in Part XI of the Convention.

101 See R. Wolfrum, 'Common Heritage of Mankind', in Max Planck Encyclopedia of Public International Law (Oxford University Press, 2013). 
states from adopting a strong environmental protection regime that turns Antarctica into a natural reserve, devoted to peace and science. ${ }^{102}$

The principle of common heritage is an appropriate basis to address global environmental issues from a redistributive perspective. This may be a radical change in a context where states still negotiate overwhelmingly on the basis of their national self-interest. Yet, the urgency of finding a new basis for addressing global problems is highlighted by developments in the climate change regime. Indeed, the move away from internationally negotiated differentiation in the context of the environmental issue most easily identified as being global is a move in the wrong direction. Individual differentiation based on narrow national interests does not point the way towards new forms of international cooperation that will ensure that climate change is comprehensively and effectively addressed. Rather, it confirms that we are reaching a roadblock and must find new ways to address crucial international environmental problems.

Starting points could be made with resources that are already under some form of joint management, such as Antarctic water resources. ${ }^{103}$ Other resources will need different starting points. The regulation of freshwater, for example, could start from the premise that the governed resource is water found in the atmosphere, which happens to be the source of most of the water humankind uses on a daily basis through precipitation, rather than surface water or groundwater located in the territory of a specific state. The water neither belongs to any state nor is subject to appropriation. This alternative perspective constitutes a good basis for new forms of regulation based on common heritage. ${ }^{104}$ There is no reason why climate change could not be addressed similarly in terms of the common responsibility that all states must anthropogenic global warming rather than the current model which is based, in effect, on rights to pollute.

102 Protocol on Environmental Protection to the Antarctic Treaty, Madrid (Spain), 4 Oct. 1991, available at: http://www.ats.aq/documents/recatt/Att006_e.pdf and Franck, n. 95 above 92.

103 J. Sohnle, 'Le principe des responsabilités communes mais différenciées dans les instruments conventionnels relatifs aux eaux douces internationales - Cherchez l'intrus!' (2014) 55(1) Cahiers de Droit, pp. 221-264, at 251.

104 See P. Cullet, 'Water Law in a Globalised World - The Need for a New Conceptual Framework' (2011) 23(2) Journal of Environmental Law, pp. 233-254, at 243. 


\subsection{Expanding Differential Treatment to All Sustainable Development- related Agreements}

Differential treatment developed in the context of the adoption of various treaties in what was a fast growing new branch of international law, IEL. The approach seemed promising for environmental issues and more generally appeared to point towards a new way of reconciling the different aspirations of the North and the South within the relatively rigid framework of international law based on legal equality and the reciprocity of obligations. The promise was in part linked to in the perception that environmental negotiations were much less acrimonious than negotiations on economic matters in earlier decades. ${ }^{105}$

In the past decades, differentiation has not only become an intrinsic part of IEL but has also progressively become a part of soft law instruments in the field of sustainable development, as last confirmed in the 2030 Agenda for Sustainable Development. ${ }^{106}$ In this sense, an understanding of the need to take a broader view of the environment seems to have developed. The language of sustainable development has progressively become the context within which the environment is considered. A long process of change, kick-started with the Brundtland Commission report, ${ }^{107}$ led to the mainstreaming of sustainable development as the new framework guiding overall UN development policy until 2030 through the adoption of the Sustainable Development Goals (SDGs).

The mainstreaming of overlapping understandings of environmental and developmental policy has surprisingly not led to a rethinking of the structure of legal obligations in the variety of areas that make up the field of sustainable development, beyond what is understood to fall under an environmental heading. This needs to change, as illustrated by the fact that some areas of international law that predate the development of environmental law, such as water law, have been largely immune to developments in environmental law. Interestingly, while water has been considered as part of environmental law since the latter's inception, the reverse has not happened. Water law has made little progress in integrating environmental principles and, as a result, there is little space for differential treatment in existing

105 See Cullet, n. 1 above at 8.

106 UN General Assembly Resolution 70/1, note 2 above.

107 N. 3 above. 
international water law instruments. ${ }^{108}$ Yet, differentiation is as imperative here as it is in environmental law.

This is illustrated, for instance, in the case of groundwater. The draft International Law Commission (ILC) articles on groundwater assert as a basic principle state sovereignty over aquifers. ${ }^{109}$ Not only does this go completely against the idea of considering water as a common heritage, but it is also a step back from the principles governing transboundary watercourses, in which elements of cooperation are recognized. ${ }^{110}$ The assertion of sovereignty is an inappropriate starting point for joint conservation and use of aquifers and for the introduction of differential treatment measures within this framework. Yet, differentiation cannot be completely ignored in attempts to regulate resources such as water. This is highlighted by the fact that, notwithstanding sovereignty assertions, the draft articles recognize the need to take into account the special situation of developing countries and include a specific provision on technical cooperation with developing countries. ${ }^{111}$

The limited recognition of the special situation of the South in the draft articles on groundwater confirms that there is a gap which needs to be addressed more systematically. Water law is one of the major areas of sustainable development where further action on this point is crucial. More broadly, differentiation must be integrated in all related areas of sustainable development. This includes key and controversial issues such as land, agriculture and mining governance:

Land may be the resource most clearly associated with the territory over which states claim sovereign control. Yet, states have already managed to agree on forms of cooperation over land degradation (and desertification). General cooperation on land issues will take time, but the link between land and many important environmental issues will eventually compel broader thinking and the recognition of the shared nature of land on the planet.

Agriculture constitutes the single most important sector in terms of livelihoods in the South. It is also the only sector where the majority of states managed to agree on a common heritage

108 Sohnle, n. 103 above at 223.

109 International Law Commission, Draft Articles on the Law of Transboundary Aquifers, Official Records of the General Assembly, Sixty-third Session, Supplement No. 10 (A/63/10), available at: http://legal.un.org/ilc/documentation/english/reports/a_63_10.pdf, Art. 3.

110 See S.C. McCaffrey, The Law of International Watercourses (Oxford University Press, 2007).

111 International Law Commission, n. 109 above, preamble and art. 16 
equity framework to govern access to seeds, even though seeds are physically clearly under sovereign control. The principle of common heritage of humankind was enshrined in the nonbinding 1983 International Undertaking on Plant Genetic Resources (IU). ${ }^{112}$ There was, however, a rapid evolution in the 1980s that led to the CBD being based on the principle that states have sovereign rights over all their biological resources. ${ }^{113}$ The 2001 International Treaty on Plant Genetic Resources for Food and Agriculture (IT PGRFA), ${ }^{114}$ is like the CBD premised on the principle that states have sovereign rights over seeds. At the same time, attempts to retain elements of the free movement of seeds put in place previously through a mechanism to foster exchanges in recognition of the vital importance of cooperation to ensure food security in a context where all states depend in part on germplasm from other countries for their main food crops. ${ }^{115}$

Mining is also an interesting case study. Under the guise of tightly controlled national legal frameworks, an increasing web of international legal instruments influences the sector, affecting areas such as climate change-related policies, land-related regulations and human rights policies relating to, for instance, mine workers or people displaced by mines.

These examples highlight the interdependence between the different sectors that make up sustainable development and the impossibility to effectively address environmental problems on a North-South basis by focusing on a limited number of issues. There is no doubt that the issues presented here, such as water, land, mining and agriculture are among the most controversial because they touch on core functions of each state. Yet, in a globalized context where environmental issues know no boundaries and the economy of every state is closely integrated in the global economy, these sectors need to be addressed upfront. Each field raises major North-South questions that need to be addressed in a context of differential treatment.

112 International Undertaking on Plant Genetic Resources, Res. 8/83, Report of the Conference of FAO, 22 $2^{\text {nd }}$ Sess., Rome 5-23 November 1983, Doc. C83/REP, available at: http://www.fao.org/docrep/x5563E/X5563e0a.htm\#e.\%20plant\%20genetic\%20resources\%20(follow\%20u p\%20of\%20conference\%20resolution\%20681.

113 Convention on Biological Diversity, n. 35 above.

114 Rome (Italy), 3 Nov. 2001, 29 June 2004, available at: http://www.planttreaty.org.

115 See H.D. Cooper, 'The International Treaty on Plant Genetic Resources for Food and Agriculture' (2002) 11(1) Review of European Community \& International Environmental Law, pp. 1-16. 


\subsection{Ensuring that Differentiation Benefits the Most Disadvantaged Individuals in Every Country}

Differential treatment has until now failed to account for the diversity of people and situations that occur within states. It is important to ensure that international principles and rules, and especially environmental laws, consider the complexity within states, particularly enormous states like China and India.

It is time for differential treatment to be conceived in a broader way; one that may still use the nation state as the basic unit for regulatory measures but that looks beyond to consider additional factors which may result in a state being assessed differently depending on the issue considered. Thus, contributions to environmental degradation or environmental harm are not necessarily equally shared throughout a whole territory. Further, countries are themselves replete with inequalities between people and differentiation must ensure that its benefits mostly reach the most disadvantaged in a given country.

One of the big challenges that international law needs to address is to see through the veil of sovereignty, for instance, when allocating responsibility for environmental damage and its remediation. The question that arises is how to measure a country's responsibility and capacity in relation to the situation of its least disadvantaged members. A country that is resilient in the aggregate may still need to benefit from differentiation if the majority of its population is vulnerable and likely to suffer disproportionately from environmental harm.

This situation is well illustrated in the case of India. In a worldwide comparison, India has experienced a period of fast economic growth since at least the beginning of the century. Significant economic reforms ushered in in 1991 have had very positive outcomes for a minority of the population. ${ }^{116}$ At the same time, growth was unequal and the situation of the vast majority of the population did not improve proportionally. ${ }^{117}$ This is reflected in the HDI. Whereas India was $123^{\text {rd }}$ out of 160 ranked countries in 1991 by the United Nations Development Programme (UNDP), it is today $136^{\text {th }}$ out of 187 countries. ${ }^{118}$ These figures

116 See J. Drèze \& A. Sen, An Uncertain Glory - India and Its Contradictions (Princeton University Press, 2013), p. 45.

117 Ibid., at 216 noting that there is 'much evidence of growing economic inequality in India in recent decades'.

118 UNDP, n. 68 above at 212. 
match the reality of a country that still has the second-highest estimated number of undernourished people in the world. ${ }^{119}$

In terms of differential treatment, an equitable international law must ensure that measures taken reflect not only the resilience of the country as a whole but also of its inhabitants. Measures that would threaten the livelihood of the majority of poor people of a resilient country would be unacceptable. This makes international policy-making slightly more complicated but not impossible. Pressure points can be inserted so that differential measures primarily affect the richest in any country. This would, for instance, be the case for measures that increasing the cost of flying, as they would disproportionately fall on the small minority of frequent fliers.

This example is relevant for climate change. Differential allocation of rights to pollute has been debated for decades. One of the proposals put on the table is to create a per capita entitlement. This would be differential since per capita emissions were and remain much lower in the South than in the North. ${ }^{120}$ While this proposal is instinctively attractive from a distributive justice perspective and provides a good starting point for a North-South conversation on allocation, it needs further reflection. On the one hand, political consensus around this formula is unlikely to emerge since it generally goes against the interests of the North as a whole. On the other hand, a simple per capita formulation is too simplistic and tends to favour bigger countries rather than the most vulnerable and least resilient countries. Further, it does not take into account the vast inequalities in emissions within individual countries. A step forward in the debate would thus be to consider actual individual emissions. In a context of vast intra-country inequalities, all countries have a minority of high emitters and a majority of low emitting residents. This could be used to build a more refined understanding of climate policy that takes into account, for instance, the existence of some low emitters in countries of the North and some high emitters in countries of the South. ${ }^{121}$ In this context, frequent fliers can become the target of measures in more or less every country on the planet.

119 FAO, IFAD and WFP, The State of Food Insecurity in the World 2015 (FAO, 2015), p. 15.

120 See A. Agarwal, 'A Southern Perspective on Curbing Global Climate Change', in S.H. Schneider, A. Rosencranz \& J.-O. Niles (eds.), Climate Change Policy - A Survey (Island Press, 2002), pp. 375-391, at 387.

121 S. Chakravarty et al., 'Sharing Global CO2 Emission Reductions Among one Billion High Emitters' (2009) 106(29) Proceedings of the National Academy of Sciences USA, p. 11884-11888. 


\section{CONCLUSION}

Differential treatment is an important instrument to foster equity in international law. It has become one of the hallmarks of IEL and is found in most legal instruments in different forms. At the same time, opposition to certain forms of differentiation or to non-reciprocity itself has persisted. It has thus been argued that differentiation should be at best temporary, that it fails to target beneficiaries appropriately, and that it undermines environmental outcomes. Opposition has been particularly virulent in the climate change context where the nonreciprocity of the Kyoto Protocol was never fully accepted and eventually led to the introduction of much weaker individual differentiation in the Paris Agreement.

This article has argued that the critiques of differential treatment are only helpful to the extent that they help to guide states towards strengthening equity measures in place. In a context of continued inequality, more rather than less differentiation is needed. This differentiation must be structured around new environmental and social bases that better reflect the problems addressed. Further, differentiation must be understood as a pre-condition for any successful international environmental regime rather than as a potential obstacle.

Overall, differential treatment in environmental matters has made a significant contribution to the development of an alternative framework for North-South relations in international law. Yet, worsening environmental conditions and an evolving global context call for adding new elements to the existing framework for differentiation. This article has posited that the first stumbling block that needs to be addressed is the organization of differentiation around nation states in a context of environmental problems that are international or global in scope. Environmental problems must be addressed at the global level, which can be achieved if the environment is treated as a common heritage. The regulation of environmental problems at the global level provides the basis for equity measures that transcend the nation state, as already implemented in some limited contexts.

Further changes are needed in the way in which differentiation is applied. Differentiation must be applied not only in what is usually known as environmental law but more broadly in all sectors of sustainable development. This will ensure that similar measures are taken in all related fields. In addition, the limited view of differentiation that stops with the nation state 
needs to be expanded to ensure that differential measures benefit not just a country in general but the most disadvantaged individuals as a matter of priority. This is particularly important since differentiation in favour of disadvantaged states does not necessarily lead to policies that favour disadvantaged individuals.

The various measures suggested here will help to strengthen the overall context within which differentiation is conceived and to address recurrent critiques. Both are necessary to foster a vibrant international environmental law that meets the equity needs of all states in years to come. 